\title{
RELIGIÕES AFRO-BRASILEIRAS E O OLHAR PSIQUIÁTRICO-ANTROPOLÓGICO DE RENÉ RIBEIRO
}

\author{
Walkyria Chagas da Silva Santos 1 \\ DOI 10.26512/revistacalundu.v3i2.23995
}

$\mathrm{Na}$ transição entre o final do século XIX e início do século XX alguns teóricos começaram o estudo das religiões afro-brasileiras, tais estudos estavam concentrados no olhar psiquiátrico-antropológico das religiões. Na Bahia, o nome de grande destaque foi Nina Rodrigues e, no Recife, destacou-se René Ribeiro. Em 1952, René Ribeiro publicou o livro "Cultos Afrobrasileiros do Recife: um estudo de ajustamento social". Em 2014, ano do centenário do pesquisador, a obra foi relançada no livro "René Ribeiro e a Antropologia dos Cultos Afro-brasileiros". O livro é importante para entender a análise patologizante das religiões afro-brasileiras e a abordagem da democracia racial no âmbito religioso.

Obra publicada após 20 anos da publicação do livro "Os Africanos no Brasil", de Nina Rodrigues, o grande interesse de René Ribeiro em "Cultos Afrobrasileiros do Recife: um estudo de ajustamento social" (1952) não é demonstrar o transe como sonambulismo, mas sim relatar sobre a aculturação e, principalmente, o ajustamento social dos negros, a partir da Psiquiatria, da Psicologia e da Antropologia Cultural.

O que René Ribeiro denomina de ajustamento social, “[...] concerne ao metabolismo (para usar uma metáfora funcionalista, abordagem que parece também influenciar a obra de Ribeiro) interno do grupo de culto, mas também externo, na medida em que ele dirimiria revoltas e angústias e reservaria sua manifestação a um ambiente controlado" (PORTUGAL, 2014:7).

Os trabalhos de René Ribeiro inauguram um segundo momento dos estudos psiquiátricos sobre as religiões afro-brasileiras, em especial sobre o Xangô de Pernambuco. Se Nina Rodrigues "apostava" no desaparecimento das religiões afrobrasileiras, em contrapartida René Ribeiro buscava demonstrar que a aculturação dos negros não resultou no apagamento dos costumes e das crenças, mas sim permitiu a integração destas em uma nova configuração estrutural (PORTUGAL, 2014).

\footnotetext{
${ }^{1}$ Doutoranda na Universidade de Brasília
} 
O estudo que René Ribeiro apresenta é resultado de trabalho de campo realizado nos períodos de 1947/1948 e 1951/1952. O autor relata que a maior dificuldade enfrentada e que não foi vencida por Nina Rodrigues era a de não ficar subordinado à hierarquia do culto, aos domínios dos babalorixás. O que garantiu o êxito da pesquisa foi a sua categoria de confidente-simpatizante em decorrência da sua atuação junto aos sacerdotes no Serviço de Higiene Mental da Assistência a Psicopatas.

O pesquisador ressalta que a proteção constitucional para a liberdade de culto, assim como ocorre hoje, não era suficiente para impedir a perseguição e violência. Sem problematizar os dados, ele apresenta o perfil dos locais de culto e dos freqüentadores. Os terreiros estavam localizados nos subúrbios da cidade, eram frequentados por população de nível econômico e social mais baixo, predominantemente por "indivíduos negros e mestiços escuros, analfabetos ou com pouca instrução" (apesar de possuírem vários livros sobre o culto) que exerciam profissões humildes (RIBEIRO, 2014).

Ribeiro traz em algumas passagens a afirmação que os negros se comportam como brancos desejando ser um deles, conforme transcrito a seguir: "Seu pai, igualmente à maioria dos antigos sacerdotes, desejava vê-lo bem sucedido em atividade estranha ao culto e mais acorde com os modelos culturais europeus" (RIBEIRO, 2014:91).

É necessário destacar que, em alguns momentos, Ribeiro denomina os fiéis de dançarinos e as festas religiosas públicas de festivais públicos. Em mais de uma passagem o autor relata as punições aplicadas aos adeptos faltosos, inclusive punições físicas. Assim, sem nomear, em alguns trechos fica evidenciado que o autor, assim como Nina Rodrigues, considera que a religião possui práticas primitivas.

São nas punições e no transe que René Ribeiro faz suas analises na área médica de forma mais clara. A possessão é denominada de obscuro fenômeno psicológico, e da possessão, segundo o autor, deriva a liberação de tensões psicológicas, aprovação e consideração do grupo. Tal é a importância psicológica da possessão que a ausência dela gera frustração.

Apenas no final do livro René Ribeiro apresenta o termo ajustamento, um termo da área da psicologia. Segundo o autor, a partir da religião afro-brasileira, o indivíduo permite a satisfação de necessidades psicológicas que são indispensáveis a seu ajustamento social ao mundo em que vive e se constitui em experiências mais satisfatórias do que qualquer outra que a sociedade possa lhe proporcionar. A partir da 
religião o individuo não só tem contato com o sobrenatural, mas também encontra apoio psicológico para enfrentar os seus problemas diários.

René Ribeiro coloca os espaços religiosos como locais de transmissão de elementos culturais africanos, mas também é possível perceber certa ironia em sua análise, vejamos, "Outra sacerdotisa referia muito convicta que os orisha consumiam da água depositada em quartinhas de barro poroso diante de seus altares. Chegando no outro dia, encontrava o nível do líquido baixo [dada a evaporação natural], daí sua certeza de que a água fora gasta pelo "santo"...” (RIBEIRO, 2014: 115).

E é razoável perceber da leitura do livro "Cultos Afrobrasileiros do Recife: um estudo de ajustamento social” que René Ribeiro busca suavizar a violência sofrida pelos negros, não problematizando os dados encontrados quanto a raça e deixando em evidência a questão econômica, provavelmente por ser influenciado pelo mito da democracia racial.

Nas palavras de Portugal, "É interessante perceber que a expressão "democracia racial" passa a ser utilizada na literatura acadêmica em 1952, o mesmo ano da primeira publicação de "Cultos afro-brasileiros do Recife" (1978), uma das principais obras de René Ribeiro" (PORTUGAL, 2014:6-7). Ainda que René Ribeiro não utilize a nomenclatura "democracia racial" fica cristalino o seu alinhamento a tal corrente ao escrever a partir do apagamento dos conflitos raciais no Brasil.

Abdias do Nascimento em "O genocídio do negro brasileiro", na década de 70, analisava as consequências dos estudos sobre os negros. Para ele, René Ribeiro escreveu monografias descritivas, de pretenso interesse científico, de caráter acadêmico, mas que para o negro nada trouxe de útil. Tais estudos vêem o negro como mero objeto "dissociado de sua humanidade, omitindo sua dinâmica histórica, e as aspirações de sentido político e cultural do negro brasileiro. São estudos de vista curta, em geral considerando os povos africanos e negros como "interessantes" e/ou "curiosos" " (NASCIMENTO, 1978:35).

Além da publicação do original do livro "Cultos Afro-brasileiros do Recife: um estudo de ajustamento social", o livro "René Ribeiro e a Antropologia dos Cultos Afrobrasileiros" traz o posfácio de Celina Ribeiro Hutzler, organizadora do livro e filha do pesquisador; fotografias de Pierre Verger e Cecil Ayres; dois artigos sobre René Ribeiro, um de Roberto Motta ("René Ribeiro ou a Paixão do Concreto") e outro de Antonio Motta e Renato Athias ("René Ribeiro e a institucionalização da Antropologia em Pernambuco"); ensaio fotográfico da III Reunião Brasileira de Antropologia, 1958; 
"Notas Biográficas sobre René Ribeiro" de autoria de Heraldo Souto Maior; e ao final é apresentada a bibliografia de René Ribeiro, com as publicações do pesquisador de 1935 a 1989.

Sem perder de vista a análise patologizante das religiões afro-brasileiras, René Ribeiro traça o caminho para a abordagem da democracia racial no âmbito religioso, compreendendo as religiões não pelo seu potencial de agência negra, mas como instância reguladora da população negra. Portanto, o livro é uma fonte bibliográfica para entender o tratamento dispensado pela ciência e pela academia para as religiões afrobrasileiras.

\section{Referências bibliográficas}

NASCIMENTO, Abdias. O genocídio do negro brasileiro: processo de um racismo mascarado. Rio de Janeiro: Editora Paz e Terra, 1978.

PORTUGAL, Clarice Moreira. "A construção de um olhar psiquiátrico-antropológico acerca dos cultos de matrizes africanas no Brasil: uma perspectiva histórica". Anais Eletrônicos do $14^{o}$ Seminário Nacional de História da Ciência e da Tecnologia $-14^{\circ}$ SNHCT. Belo Horizonte, Campus Pampulha da Universidade Federal de Minas Gerais UFMG.

Disponível

em: <https://www.14snhct.sbhc.org.br/arquivo/download?ID_ARQUIVO=1663>. Acesso em: 05 fev. 2019.

HUTZLER, Celina Ribeiro (Org.). René Ribeiro e a antropologia dos cultos afrobrasileiros. Recife: Ed. Universitária de UFPE, 2014.

RODRIGUES, Nina. Os africanos no Brasil. Rio de Janeiro: Centro Edelstein de Pesquisas Sociais, 2010.

Recebido em: 04/08/2019

Aceito em: 05/09/2019 